Meta

Journal des traducteurs

Translators' Journal

\title{
Shifts in Patronage Differentiation: Translation from European Languages in Isolationist Japan
}

\section{James Hadley}

Volume 61, numéro 3, décembre 2016

URI : https://id.erudit.org/iderudit/1039226ar

DOI : https://doi.org/10.7202/1039226ar

Aller au sommaire du numéro

Éditeur(s)

Les Presses de l’Université de Montréal

ISSN

0026-0452 (imprimé)

1492-1421 (numérique)

Découvrir la revue

Citer cet article

Hadley, J. (2016). Shifts in Patronage Differentiation: Translation from European Languages in Isolationist Japan. Meta, 61(3), 709-726.

https://doi.org/10.7202/1039226ar
Résumé de l'article

Cet article démontre que le mécénat des traductions peut aller imperceptiblement de l'indifférencié au différencié. Il se concentre sur le " passage du temps » comme facteur de la conceptualisation du mécénat, originairement conçu par Lefevere. Actuellement, cette conceptualisation analyse l'Histoire comme une série d'instantanés avec peu d'attention portée à la notion de transition, surtout lorsqu'elle concerne le passage d'une forme de mécénat à une autre. Après un compte rendu du développement du mécénat des traductions au début de l'histoire moderne du Japon, cet article explore la dynamique du mécénat des traductions pendant une période de plus de deux siècles lorsque le pays a maintenu une politique d'isolationnisme national. En vertu de cette politique, le christianisme est devenu absolument tabou, et ceux qui y étaient associés étaient considérés avec la plus grande suspicion. Cependant, un collège d'interprètes d'État permettait le maintien d'un niveau restreint de relations commerciales internationales. Dans ce système, le mécénat des traducteurs au Japon était extrêmement indifférencié, provenant exclusivement de sources gouvernementales. Toutefois, avant la chute de ce système, le modèle du mécénat était déjà différencié et les services de traduction étaient recherchés par un large éventail de parties intéressées, hors du cadre du gouvernement.
Ce document est protégé par la loi sur le droit d'auteur. L’utilisation des services d’Érudit (y compris la reproduction) est assujettie à sa politique d'utilisation que vous pouvez consulter en ligne.

https://apropos.erudit.org/fr/usagers/politique-dutilisation/ 


\title{
Shifts in Patronage Differentiation: Translation from European Languages in Isolationist Japan
}

\author{
JAMES HADLEY \\ Nanjing Agricultural University, Nanjing, China \\ james.hadley@ed-alumni.net
}

\section{RÉSUMÉ}

Cet article démontre que le mécénat des traductions peut aller imperceptiblement de l'indifférencié au différencié. II se concentre sur le «passage du temps» comme facteur de la conceptualisation du mécénat, originairement conçu par Lefevere. Actuellement, cette conceptualisation analyse l'Histoire comme une série d'instantanés avec peu d'attention portée à la notion de transition, surtout lorsqu'elle concerne le passage d'une forme de mécénat à une autre. Après un compte rendu du développement du mécénat des traductions au début de l'histoire moderne du Japon, cet article explore la dynamique du mécénat des traductions pendant une période de plus de deux siècles lorsque le pays a maintenu une politique d'isolationnisme national. En vertu de cette politique, le christianisme est devenu absolument tabou, et ceux qui y étaient associés étaient considérés avec la plus grande suspicion. Cependant, un collège d'interprètes d'État permettait le maintien d'un niveau restreint de relations commerciales internationales. Dans ce système, le mécénat des traducteurs au Japon était extrêmement indifférencié, provenant exclusivement de sources gouvernementales. Toutefois, avant la chute de ce système, le modèle du mécénat était déjà différencié et les services de traduction étaient recherchés par un large éventail de parties intéressées, hors du cadre du gouvernement.

\section{ABSTRACT}

This article demonstrates that translation patronage can shift imperceptibly between being undifferentiated and differentiated. It focuses on the passage of time as a factor that could be added to Lefevere's conceptualization of patronage. Currently this conceptualization approaches history as a series of snapshots, with little focus on transition, most importantly, between one form of patronage and another. With an overview of the development of translation patronage in early modern Japanese history, this article explores the dynamics of translation patronage over a period of well over two centuries, when the country maintained a policy of national isolationism. Under this policy, Christianity became absolutely taboo, and those associated with it were regarded with utmost suspicion. Yet, limited international trade was permitted to continue by a stateowned collegium of interpreters. Under this system, the patronage of translators in Japan was extremely undifferentiated, being obtained solely from governmental sources. However, before the end of this system, patronage had already shifted to a differentiated model, in which translation services were being sought by a wide range of parties beyond the government.

\section{MOTS-CLÉS/KEYWORDS}

mécénat, Japon, interprètes, histoire du traduction, isolationnisme patronage, Japan, interpreters, translation history, isolationism 


\section{Introduction}

Examples such as foreignization/domestication, Skopostheorie, and the explicitation hypothesis demonstrate that both in terms of translation theory's formulation and ultimate popularity, significant emphasis has historically fallen on the subject of translator agency. By comparison, the subject of patronage has enjoyed relatively limited engagement. André Lefevere's (1982, 1992: 11-72) discussions are the discipline's most authoritative on the subject. Somewhat unusually for the discipline, his findings are not drawn from case studies. Instead, Lefevere draws on numerous discrete examples from an array of times and cultures to illustrate his paradigm of patronage as a universal feature of literary systems:

Patronage can be exerted by persons, such as the Medici, Maecenas, or Louis XIV, and also by groups of persons, a religious body, a political party, a social class, a royal court, publishers, and, last but not least, the media, both newspapers and magazines and larger television corporations (Lefevere 1992: 15).

Being a generalisable principle, Lefevere sees little need to differentiate between cultural or linguistic contexts in his discussion of the mechanics of patronage. While Lefevere's conceptualization can be seen as a neat expression of the mechanics behind translation patronage, his approach is one that condenses the phenomenon by examining patronage as it exists at specific points in history. Lefevere acknowledges that substantial changes can occur in the nature of a literary system's form of patronage (Lefevere 1992: 23), though he does not explore these in detail. This article aims to argue that the passage of time, added to Lefevere's conceptualization may be a topic for future research. It will explore a system of patronage as it existed over a substantial period of time, and employ this to analyse the manner in which transitions in the nature of patronage can occur.

In order to facilitate this consideration of patronage over an extended period, this article will not adopt Lefevere's generalizing tendency. Instead, it will focus on a single case study, spanning a period of well over two centuries. It begins in 1612, when Japan's foreign policy went from one of widespread engagement in Asian and European international trade, to one of near total, self-imposed isolation from the outside world. During this period, foreign ships were banned from docking, Japanese ships were banned from sailing outside domestic waters, and those Japanese already living abroad were forbidden from returning. However, the country was never totally cut off. A small number of foreign vessels each year was permitted to dock for trade, and a small population of foreign nationals was tolerated the year-round in order to enable this trade. These foreigners were segregated from the Japanese, and prohibited from learning the Japanese language. To cope with the necessity of intercultural communication, and to restrict its extent and impact, the country's rulers and instigators of isolationism set up a system of native, often hereditary Japanese interpreters. The focus of this article will be on the development of the increasingly complex relationship between the interpreters and their patrons over the term of its existence.

\section{Patronage}

Lefevere's conception of patronage is ultimately derived from the conception of the 'system' that predominates in general systems theory and Russian formalism 
(Lefevere 1982: 5). Within this paradigm, a given culture is made up of a number of discrete, but interrelated systems, each of which governs a particular cultural facet such as literature. According to formalism, these systems are inherently incomplete, and so, necessarily interact, influence, and revitalize one another according to a form of logic that is particular to each culture (Berger 2005: 6). Lefevere's conception of patronage is intended to go some way towards describing the mechanics behind these inter-systemic interactions by suggesting that patrons are the ones who control this logic (Lefevere 1992: 14). Thus, patrons are responsible for regulating the amount of influence one system or subsystem can have on any other, since any such interaction is reliant on the actions of human beings, who are ultimately constrained by financial, and societal needs:

A 'patron' is any kind of force that can be influential in encouraging and propagating, but also in discouraging, censoring and destroying works of literature. Patrons can be individuals, and they come most readily to mind in this guise [...]. But they can also be institutions, such as the Roman Catholic Church, the Communist Party, the BBC (Lefevere 1984: 92).

Thus, in the case of translation, the role of the patron is not merely one of an impartial force that sets the wheels in motion. Rather, the patron retains a tangible presence throughout the process, controlling the output, such that it does not move too far away from the other systems that make up the culture (Lefevere 1982: 6).

In this sense, Lefevere sees the effects of patron relationships as being ultimately limiting, given that translations cannot continue to be produced without patronage, and given that translations require translators for their production. Lefevere conceptualizes this relationship of mutually reliant partners as constituting a "double control factor," which has a constraining effect over the literary subsystem, ensuring that it does not "fall too far out of step with the other subsystems society consists of" (Lefevere 1992: 14). The translator relies on the patron for legitimacy and a livelihood, while the patron relies on the translator for the production of the translation work. Any interest in stepping far beyond the extant norms of the target culture on the part of translators will be kept in check by their financial, societal, and ideological need for their work to attain continued patronage, while patrons' ability to influence the production of translations is limited by their ability to influence translators.

Lefevere conceptualizes patronage as being either differentiated or undifferentiated. Undifferentiated patronage occurs when the translator derives status, economic support and ideological legitimacy from one individual or group. Differentiated patronage, on the other hand, occurs when ideology, status, and economic success are less tightly interwoven, being acquired from a variety of sources (Lefevere 1992: 17; 1982: 6). Thus, the degree to which the "double control factor" is capable of influencing the production of translations, together with the manner in which this influence is manifest differs significantly, depending on the category of patronage in evidence. In the case of undifferentiated patronage, the translator is entirely reliant on a single patron, and so, has a vested interest in not acting in such a way as to jeopardize this relationship. The patron is, therefore, able to exert relatively direct control over the translator and the work produced. Differentiated patronage, on the other hand, allows translators potentially to acquire status, money, and ideological recognition all from distinct sources, meaning that those working under this kind of system are comparatively free from direct pressures, and able to continue their 
work provided that it finds a market of some kind. It is, perhaps, because of the comparatively high degree of control afforded by undifferentiated forms of patronage that Lefevere links them with totalitarian forms of government (Lefevere 1992: 17). Differentiated patronage, on the other hand, is seen as functioning "by means of institutions set up to regulate, if not the writing of literature, at least its distribution: academies, censorship bureaus, critical journals, and, by far the most important, the educational establishment" (Lefevere 1992: 15).

During Japan's isolationist period, translation and interpreting from European languages were closely regulated, to the extent that they were activities restricted to an identifiable body of state-sponsored interpreters. Ostensibly then, this case neatly illustrates Lefevere's conceptualization of undifferentiated patronage. However, when the whole expanse of time during which this system existed is taken into consideration, any such classification becomes more problematic.

\section{Isolationism and Shogunal Authority}

At the time, Japan was under the rule of the Tokugawa shoguns, who controlled the country from 1600 to 1867 . Because of a perceived threat to their authority posed by Christianity, the shoguns adopted an increasingly extreme policy of isolationism, which came to characterize their rule (De Bary et al. 2006: 4-5).

Portuguese sailors had first landed on Tanegashima, off the southern island of Kyushu, in 1543 and quickly established trade with the Japanese, most notably in firearms (Lidin 2002: xi, 16). However, this Portuguese trade was intricately intertwined with Catholic missionary activity, and the arrival of Francis Xavier and two fellow Jesuit missionaries in 1549 began a long tradition of Catholic proselytisation and Japanese conversion (Laver 2011: 6; Phan 2011: 212).

In 1570, the Jesuits founded the port of Nagasaki, which would become the Portuguese hub of activity in Japan (Pacheco 1970: 306). This small fishing port rapidly developed into a busy trading harbour, where Portuguese ships arrived from the colony of Macau on the Chinese mainland. ${ }^{1}$ Indeed, from 1580, Nagasaki was something of a parallel to Macau, being under the direct jurisdiction of the Jesuits (Cullen 2003: 32). This situation did not last long, however. In 1587, Toyotomi Hideyoshi (豊臣秀吉), the unifier of Japan following two centuries of civil war, acted to curb the growing potential threat to his authority posed by the Europeans. This threat was embodied by the fact that Japan's Christian community had steadily continued to grow, having already claimed nearly two percent of the whole Japanese population by the end of the sixteenth century (Jansen 2002: 28). Moreover, because the Catholic faith brought by the Portuguese fundamentally entailed allegiance to a foreign, temporal ruler in the person of the Pope, the Japanese authorities had a legitimate concern that if the Portuguese imperialist ambitions that had already inspired their conquests were to shift towards Japan, trade may give way to open hostility. In this event, having a large population with divided loyalties was too great a risk. Therefore, in a single move, Toyotomi reclassified Nagasaki and its now burgeoning trade as his own private concern, and also issued the "Purge Directive Order to the Jesuits” (伴天連追放令) (Masaki 2000: 6).

The directive can be perceived as setting the scene for a number of subsequent official modifications to Japanese international policy over the next forty years that 
would retrospectively be known collectively as the Sakoku Edicts. These five edicts, enacted between 1633 and 1639 gradually imposed increasingly restrictive sanctions on the movements of people into and out of Japan, at the same time as actively working to consolidate the government's authority (Laver 2011: 35-43). The Japanese were increasingly restricted, and eventually banned from travelling overseas; Portuguese interaction with ordinary Japanese subjects was gradually curtailed, and then ceased; and European trade was limited to the Dutch, whose activities were eventually confined wholly to Dejima. ${ }^{2}$

Dejima was a small artificial island in Nagasaki bay measuring around 120 meters by 75 meters (Roberts 2009: 9). The island was connected to the mainland by a constantly supervised bridge (van der Velde 1995: 46). Dutch trading ships were allowed to dock twice per year, though the island maintained a small, year-round population of around twenty individuals (Goodman 2000: 20).

\section{The Interpreters as a Semipermeable Barrier}

It was in the shogun's interests to continue to permit this limited European trade, on the basis that it was spectacularly lucrative for the local economy of Nagasaki, his own possession. However, the Dutch traders of Dejima and their religion remained a potential chink in the country's armour of isolationism. Thus, they were kept as segregated as possible from the Japanese population, being officially forbidden from learning Japanese or leaving the island without special permission. Access to the island was also proscribed for most Japanese subjects. A public noticeboard near to Dejima bridge showed a list of the island's regulations, dominated by those who were forbidden access to the island (Katagiri 2000: 22):

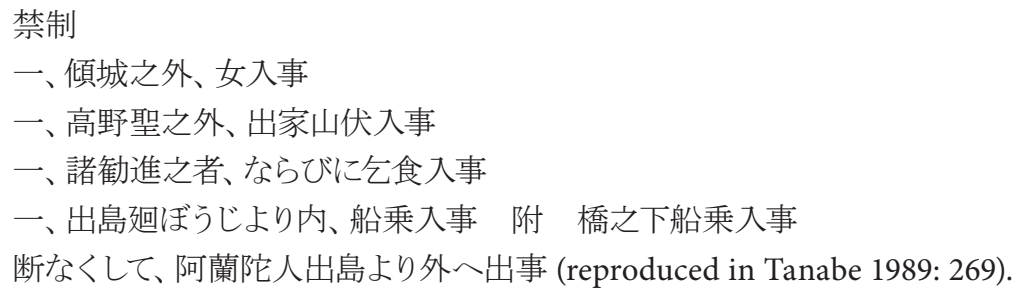

The sailing of vessels into the boundaries surrounding Dejima, and the sailing of vessels beneath the Dejima bridge

The departure of Dutch people from Dejima Island without permission]

This strict isolation of Dejima's inhabitants made the island something analogous to a quarantine zone, specifically set up to counter the potentially hazardous influences of Christianity and European culture in general. However, it was necessary to keep the barrier separating the Europeans from the Japanese semi-permeable. Movement and communication between one community and the other was necessary for trade. Therefore, a collegium of interpreters was set up directly under the 
authority of the Nagasaki Bugyō in order to act as the intermediaries for, and administrators of, the Dutch and their trade (Laver 2011: 66-68). ${ }^{3}$

Historical data regarding the lives of Dejima's inhabitants can be found from a variety of sources. Historically, the writings of Engelbert Kaempfer have enjoyed substantial engagement, followed to a lesser degree by later European visitors to Dejima such as Carl Peter Thunberg, and more recently, by the [Journals Kept by the Heads of the Dutch Factory in Japan] (1974).

Kaempfer was a German physician employed by the Dutch East India Company, who spent two years on Dejima from September 1690. His work, Heutiges Japan, which constitutes his memoirs of Japan, was published posthumously in an English translation by John Gaspar Scheuchzer (1727). Kaempfer appears to have relied on Imamura Genenmon (今村源右衛門), one of the apprentice interpreters, as the clandestine source of much of his detailed description of the collegium and its hierarchy (van der Velde 1995: 44). This description puts the total number of individuals who were nominally interpreters at 150 persons. This figure is not corroborated by the Swede, Carl Peter Thunberg, who occupied the same position, as surgeon to Dejima eighty-five years later (Rudolph 1974: 165-166). In his own discussion of the collegium of interpreters, Thunberg (1788: 35) counts between forty and fifty professional interpreters. Taking into consideration the evolving nature of the interpreters' roles during this period, even this figure appears huge, bearing in mind the fact that Dejima could not support a permanent Dutch population of more than twenty-five people (Katagiri 2000: 28). However, unlike Thunberg's, Kaempfer's description is backed by a native informant, whose awareness of the nuances of the interpreter system subtly suggests itself, and may have corrected any immediate assumptions made by the outside onlooker. Kaempfer initially introduces the topic of interpreters as follows:

Den grösten und vornehmsten häufen holländischer bedienten machet aus das sämptliche collegium der Hollanda Tsjuunsi oder Holländischen Tolmetschen, so eine geraume Zahl von ohngefehr 150 beÿ meinem anwesen nuhr 123, als incomplet persohnen auslieferen (Kaempfer 2001: 332).

[The largest and most extensive group set up to tend to the Dutch is the collegium of the Hollanda Tsjuunsi, or Dutch Interpreters, a considerable number of around 150 people, though during my stay this number was not complete, not exceeding 123.] ${ }^{4}$

Had his Japanese informant not been aware of it, one might legitimately ask how Kaempfer could have known that the normal number of interpreters was around 150 if he had never seen the figure rise so high. Moreover, the hand of the native informant is further apparent when the two Europeans' descriptions of the collegium's hierarchy are compared. Thunberg describes the collegium's hierarchy from the perspective of an outsider, linking the various ranks to their holders' level of Dutch proficiency:

De äldste, som tala bäst Hollandska språket, få namn af öfver-Tolkar; de som tala det mindre väl, under-Tolkar och de, som ännu behöva vidare lära det, kallas Lärlingar. För detta lärde Holländarne Japonesiske Lärlingarne sjelfve språket, i synnerhet var det Doctorns sysla; men nu informeras desse af de äldre Tolkar (Thunberg 1788: 35). 
[The highest ranked, who speak the best Dutch are named over-interpreters; those who speak less well, under-interpreters, and those who still need to learn are called apprentices. Formerly it was the Dutch who taught the Japanese apprentices their own language, in particular, it was the doctor's duty, but now they are taught by the more senior interpreters.]

This hierarchy is straightforward. Indeed, it is extremely so, compared to the description provided by Kaempfer, who describes a two-tier structure encompassing a body of regular interpreters: "derer erste, als ordinairer Tolmetschen, die holländische Insel nach belieben besuchen mag” (Kaempfer 2001: 274) [the first, or regular interpreters, who may visit the Dutch island at will], and another of interpreters who appear to specialize in the administration of the Dutch auctions: "die andere wird nuhr zuletzt in der negotie zugelassen, mehr der augen zur auffsicht, als der Zunge zum Tolmetschen zugebrauchen" (Kaempfer 2001: 274) [the others, only admitted during the time of our sale, use their eyes to keep watch over us more than they do their tongues to interpret]. Thunberg's description of the interpreters focuses on their linguistic proficiency, ignoring or overlooking the importance and range of the administrative duties with which the interpreters were also charged, and which are also only hinted at by Kaempfer.

The Japanese language of the era appears to have subtly acknowledged a distinction between interpreters [tsūji] whose roles were purely linguistic, and those who also had administrative duties. According to Yokoyama (2011: 175) tsūji could either be written as 通詞, or as 通事. Both renderings comprise the character 通 (tsū), conveying the meaning of passing through. However, they differ in their use of the homophones 詞 (ji), conveying the sense of “words," and 事 (ji), conveying that of "things" or "business." In practice, however, in the context of Edo era Nagasaki, the second term is most frequently applied to the interpreters of Chinese, who are conventionally known as 唐通事 (Tōtsūji) in reference to the Chinese Tang (唐) dynasty. Conversely, the interpreters of Dutch are routinely known as 阿蘭陀通詞 (Oranda tsūji), or 蘭通詞 (Ran tsūji), both in reference to the Dutch language and people (Mozumi 1996: 839).

The third rank to the collegium's hierarchy, which Thunberg describes simply as the third class, and Kaempfer names the “Keekotsjusi” (keiko-tsūji/稽古通詞) is also significant from the point of view of the self-perpetuating nature of the collegium, and by extension, its patron-professional relationship with the shogunal government:

Nach diesen folgen die unter die oberwehnte Zahl der Tsjusi ungerechnete Keeko Lehrlinge, tsjusi, oder lernende Tolmetschen, 8 oder mehr an der Zahl, sind eigene und angenommene Söhne der besagten Tolmetschen, so die Insel täglich besuchen um die Holländische und Portugische spräche zu lernen, neben der Kunst ausländer zu regieren (Kaempfer 2001: 276):

[Next largest in number is the Tsjusi known as Keeko (apprentice) interpreters, or learning interpreters, 8 or more in number, who are the natural or adopted sons of the said interpreters. They come to the island daily to learn to speak Dutch and Portuguese, as well as the art of dealing with foreigners:]

The collegium's hierarchy illustrates the largely hereditary manner in which it functioned. In turn, this means of self-perpetuation allowed the patronage afforded to individuals engaged in interlingual and intercultural contact to be contained 
within a relatively closed system. Indeed, the closed nature of the system is further demonstrated by the range of tasks beyond linguistic interchange that were charged to the collegium, which ultimately allowed it to be held accountable for all aspects of European contact with the Japanese. Katagiri (1995: 9-11) illustrates this range of tasks, demonstrating that tsūji were responsible for checking that arriving ships were authorized to dock, taking down ships' crew lists, verifying cargo lists, checking for contraband, administering the sale of Dutch merchandise with Japanese merchants, and administering the day-to-day living conditions of Dejima's inhabitants. Indeed, the administration of Dejima and its residents warranted the establishment of a distinct subset of tsūji. Kaempfer comes last to this subset, which is not mentioned by Thunberg at all:

Nach diesen folgt die schaar derer Nai tsjusi, nach dem buchstaben inner oder Kammer tolmetschen genandt, weilen sie particulieren ausländem innerhalb Hauses beÿ seÿn müssen (Kaempfer 2001: 276).

[After these, are the droves of people called the company of the Nai tsjusi, literally meaning inner, or chamber interpreters, as they stay within the houses of foreigners.]

Kaempfer describes these individuals numbering upwards of 100, and acting as a measure against clandestine activities:

Werden als dan einen idem Holländer 2 à 6 derselben in seiner Kammer unter den Nahmen Tolmetschen, aber in Wahrheit als Coryphen zugeselt, dan unter 10 kaum einer ein teütsch wort versteht, es seÿ dan, das er, wie gebräuchlich vor junge beÿ den Holländern gedient hatte (Kaempfer 2001: 276-277).

[Each Dutchman is assigned 2 to 6 to work in his quarters under the name of interpreters. Though in truth, they are sent as spies, since fewer than one in 10 can understand a word of Dutch, that is, apart from those who, as is common, had served the Dutch before.]

It is, perhaps, natural that Thunberg chose not to describe the domestic servants in the Europeans' houses as interpreters if Kaempfer's assertions regarding their linguistic abilities are to be believed. Moreover, that they were not permanent members of the collegium, and instead worked on commission may be another reason why Thunberg did not equate the nai-tsūji (内通詞) with interpreters (de Groot 2010: 203). Indeed, as individuals charged with interacting with the Europeans, the distance the nai-tsūji were expected to maintain from them illustrates further the uneasy, quarantine-like quality of Dejima:

[...] und uns keine Conversation mit Japanern vergönt, ohne mit unsem dienern und bedienten, welche sich doch mit ihrem blute verschrieben, das Sie uns von einheimischen Sachen nichts bey bringen, noch einige Vertraulichkeit mit Uns pflegen wollen (Kaempfer 2001: 286).

[[...] and we were granted no conversation with the Japanese apart from those who served us, who were sworn by their own blood not to bring us any native things nor to seek to maintain familiarity with us.]

The unusual nomenclature of the Oranda nai-tsūji (阿蘭陀内通詞) [domestic interpreters of Dutch] has its basis in historical precedent and a lawsuit that took place in 1670, thirty years after Dutch trade was moved from Hirado to Dejima 
(Katagiri 1995: 7). When the Dutch moved, they took with them the Japanese gobetweens and servants they had always employed privately. At least eleven of these Hirado interpreters are known to have been transferred to Nagasaki, and formed into the nucleus of the new, state-run collegium of interpreters (Cullen 2003: 39). There was, therefore, a tradition of the European traders hiring Japanese employees privately to cater for a range of tasks that would naturally have included linguistic mediation. These interpreters joined their counterparts who had previously served the now expelled Portuguese (Roberts 2009: 13). However, the collegium of interpreters, its patronage and priorities, were all fundamentally different from the ad-hoc, self-regulated activities either group had known previously. The collegium was an official enterprise, sponsored by the Nagasaki Bugyō for the purposes of national security. It was charged with overseeing all aspects of trade with the Europeans, and so, was ultimately accountable for any breaches in the national isolationist policy. This shift in patronage meant that the interpreters' priorities also shifted away from the service of the Europeans, towards the protection of the Japanese state and its interests. The stability of the patronage too, was significant. The collegium appears to have favoured hereditary offices as a means both of containing the extent of European contact with Japanese individuals, and of perpetuating its own enterprise. However, their ultimate patrons were the shoguns, whose office was similarly hereditary.

Hence, for as long as both parties continued to occupy their predefined roles, the relationship remained an elegant illustration of Lefevere's conceptualization of the "double control factor" as it relates to undifferentiated patronage. The structure and relatively closed nature of the collegium ensured a knowledge monopoly, which meant the collegium's continued patronage was crucial to continued European trade. Similarly, the fact that the patronage of the collegium was ultimately derived from the shoguns, who not only held absolute authority in the country, but also had arguably the greatest vested interest in tolerating no challenge to the status quo, ensured that the collegium acted unambiguously as a cog in the machine of isolationism. The core of its remit was now to maintain the patrons' position by preventing foreign threats from entering the country at the same time as permitting trade to continue. In turn, their patrons' role was simply to continue to supply the collegium with support, in terms of ideology, economy, and status, the three elements that make up Lefevere's paradigm of differentiated patronage (Lefevere 1992: 17).

Indeed, these three factors are tightly intertwined and mutually reliant in this example. Ideology can be interpreted as the importance placed on perpetuating the shoguns' authority as rulers of Japan, something which naturally included the removal of unwanted foreign influences. The status afforded the collegium is illustrated by the cachet of being the only body charged with the administration of European trade. Finally, the significant economic support provided to the collegium is evidenced by the extremely large workforce it was capable of maintaining. In return, the collegium generated substantial wealth, within both the local and national economies, which goes some way to explaining why the Europeans were not simply expelled, and their trade ended. It also explains the diversity and scale of the collegium of interpreters' operation, which ostensibly appears greatly overblown for the administration of a biannual sale and a small year-round population. To understand this scale in full, if the city's 200 Tōjin tsūji (Chinese interpreters) are also taken into account, around one fifth of Nagasaki's 2,000 strong administrative workforce would 
have been employed as official interpreters. Cullen (2003: 60) estimates that when this figure is expanded to include dependents, the inhabitants directly supported by the bugyō would have totalled around 10,000, or a sixth of the total permanent population of Nagasaki city. With the logistical, security, and political factors in mind, it appears highly unlikely that the government would have continued to fund such a burgeoning workforce under its direct patronage if international trade were not sufficiently lucrative to the local and national economies, together with the exchequer to outweigh its associated risks and costs.

Even given the collegium's effectiveness at controlling personal and material contact between Europeans and the Japanese, the threat of Christian proselytization remained strong through the medium of the written word. Hence, under the same patronage and authority an inspectorate of written materials (書物改役/shomotsuaratame-yaku), charged with the censorship of texts entering the country functioned in cooperation with the collegium. ${ }^{5}$ For the inspectorate, however, it was the Chinese language, more than the Dutch that came under greatest scrutiny. European books per se were never banned outright. However, in practice, the number of such books that found their way into the country before the early eighteenth century is small (Cullen 2003: 131). Any work whose subject bore even a tangential relationship to Christianity was treated with the utmost suspicion. ${ }^{6}$ This suspicion extended so far as anything written in the Latin alphabet, or that merely mentioned Christian countries or regions, meaning the importation of European works was made practically impossible (Sakanishi 1937: 295). ${ }^{7}$ Thus, while texts in European languages were routinely burnt or expelled on the basis of these superficial characteristics, Chinese texts came under substantially closer inspection (Sakanishi 1937; Cullen 2003: 60). Since the 1580s, Jesuit missionaries in China had been translating Christian texts into Chinese, along with European works which, while not directly proselytizing, almost inevitably mentioned Christian themes, artefacts or locations (Mungello 2009: 86). Since the Japanese writing system is derived from, and not entirely divorced from that of China, any pro-Christian message contained within these Chinese translations could also potentially influence the Japanese. ${ }^{8}$ Thus, in the 1630 s, at the same time as the Sakoku Edicts were being issued, books in Chinese dealing with Christianity were also banned in the same zealous manner as European works. Even Chinese works on astrology and mathematics were frequently deemed inflammatory and proscribed because of passing references to Europe (Cullen 2003: 131).

These various measures against external challenges to the shoguns' authority, which were all built around the patron-professional relationship, appear to have been extremely effective, and the hereditary emphasis within the system appears to have made it largely self-propagating. The interpreters certainly succeeded in maintaining the international trade that was so fundamental to Nagasaki's economy, and the measures set in place to censure contact with Christianity were effective, though arguably overzealous. Therefore, with both partners in the relationship having a vested interest in maintaining the status quo, it is, perhaps, counterintuitive that the first seeds of change were sown by the same partnership. 


\section{The Turning Point and Written Translation}

However, a distinct turning point can be traced to the time of the eighth shogun, Tokugawa Yoshimune (徳川吉宗) (1684-1751), who saw supplying the country with an accurate calendar as part of his ceremonial duties. He ordered Nakane Genkei (中根元圭) to translate the Western Calendric System (西洋暦法/Xīyáng Lìfă), a Chinese composite translation that had hitherto been banned in Japan on account of its title (Sakanishi 1937: 297). Subsequently, during his audience with the shogun, Nakane pointed out that there were many such books in existence which may be useful to the Japanese, but these were unilaterally refused entry to Japan because of some small mention of Christianity (Sakanishi 1937: 297). His argument appears to have been convincing, since in 1720, the shogun issued an edict newly permitting books that did not intend to proselytize Christianity entry into Japan (Sakula 1985: 582).

This change in policy did not cause an immediate upsurge in the numbers of books in European languages entering Japan for two main reasons. First, while the policy change was not made in secret, no particular effort was made to publicise it (Sakanishi 1937: 299). Second, because for the past century, contact with Europeans had been essentially restricted to the collegium in Nagasaki, Japan now had no readership of any size capable of deciphering the newly permissible books. Hence, when translation did begin, it was initially at the hands of the same interpreters, at the behest of their patron, the shogun. However, both parties were also instrumental in dramatically increasing the number of Japanese citizens capable of accessing European works directly.

In 1740, hereditary interpreters Nishi Zensaburo (西善三郎) and Yoshio Kozaemon (吉雄幸左衛門) were instructed to set up the first Dutch language school in Edo (present-day Tokyo), along with the shogun's librarian, Aoki Konyō (青木昆陽), and his personal physician, Noro Genjo (野呂元丈), who were ordered to master the language for the purposes (Sakula 1985: 582). Thus, both elements of the "double control factor" cooperated, not as the restrictive force of Lefevere's conceptualization, but curiously, as a liberating force. In actively engaging with the translation of European languages, the patron did not reinforce the national policy of isolationism, but undermined it. Likewise, in effectively disseminating Dutch language knowledge beyond the confines of the relatively closed system of the collegium, the interpreters undermined their own monopoly as Japan's sole language professionals, and gave up their role as the gatekeepers of Japan's isolationism.

Still, widespread change occurred slowly. A generation went by before the first full-length translation of a text from a European language was completed. The Kaitai Shinsho (解体新書) [New Book of Anatomy], published in 1774 was preceded by a number of shorter translations of select passages. However, its production neither by the collegium, nor under the patronage of the government demonstrates that by this point, the relationship between translators and patrons had become more complex than it had been for the previous century and a half, moving decisively away from its traditional undifferentiated model.

The 120-page translation took the team of eight, headed by a physician, Sugita Genpaku (杉田玄白), some four years to produce (van Gulik and Nimura 2005: 12). ${ }^{9}$ The process was, perhaps, complicated by the fact that the source text itself, Ontleedkundige Tafelen is a 1734 translation by Gerard Dicten from the 1722 German 
work Anatomische Tabellen, by Johann Adam Kulmus (Mestler 1957: 25). Much has already been written about the milestone in Japanese scientific history this translation constituted (e.g. van Gulik and Nimura 2005, Sakula 1985, Ōtori 1964, Mestler 1957). However, it is worth pointing out how impressive the work is considering that it predates the publication of the first Dutch-Japanese dictionary, the Haruma Wage (波留麻和解), by more than twenty years.

The Kaitai Shinsho and the revelation of European medicine it generated added another layer of complexity to the patronage of translations in Japan. A new branch of medicine known as Ranhō igaku (蘭方医学) or Dutch medicine, grew rapidly, providing patronage for the production of further translations on the subject. Moreover, the norms that had seen the Europeans of Dejima almost entirely isolated from the Japanese were increasingly eroded as growing numbers of physicians and scholars sought out Dutch tutelage, either by travelling to Nagasaki itself, or by quizzing them during the mandatory, closely supervised visits the senior staff made to the capital (Goodman 2000: 126).

In turn, this growing acceptance of Dutch as a source of scientific knowledge saw the interest in translating expand beyond the boundaries of medicine. Soon, Rangaku (蘭学) or Dutch studies became a term for describing the scientific knowledge transmitted to Japan through Dutch texts, which themselves were often translations (Jansen 1984: 542). Dutch studies schools soon came to be founded around the country, further displacing the collegium as the epicentre of translation activities (Goodman 2000: 175). The career of Ōtsuki Gentaku (大槻玄沢) and its impact demonstrate how both the interpreters and the government contributed in supporting this growing interest in the outside world, contrary to their own interests. Otsuki had travelled to Edo in 1778 to study under Sugita and Maeno following their production of the Kaitai Shinsho (Hesselink 1995: 193). He then moved to Nagasaki to stay with one of the interpreters there to improve his Dutch. Subsequently, around 1788, Gentaku returned to Edo and founded the Shirando (芝蘭堂), Japan's first Rangaku school (Keene 1969: 30). Later, in 1801, he was employed directly by the government along with Nagasaki interpreter, Baba Sadayoshi (馬場貞由) and other leading lights in Dutch studies, to form the astronomer's office into an official translation bureau (Ōkubo 1986: 89). ${ }^{10}$ In this way, the government appears to have been attempting to reassert its undifferentiated patronage over translation from Dutch by monopolizing the most able of the new translators.

The official status of the translation bureau was formalized in 1811, when the astronomer's office was renamed the "Bureau for the Decipherment of Barbarian Writings,” or Banshowagegoyō (蕃書和解御用) (Goodman 2000: 119). It was also expanded, and an enormously ambitious translation project commissioned the next year (Smith 1948: 131). Baba Sadayoshi, along with yet more leading Rangaku scholars such as Koseki Sanei (小関三英), Minato Chōan (湊長安), and Ōtsuki Genkan (大槻玄幹) were formed into a seven-man translation team for Japan's first encyclopedia, which would occupy the bureau's attention for the next thirty-five years (Shidō and Yabe 1991: 94). The Kōseishinpen (厚生新編) is a translation of the Dutch encyclopedia Huishoudelijk Woordenboek (1768) by Jacques Alexandre de Chalmot, which is, itself, a translation from Noël Chomel's Dictionnaire œ conomique (1718). A huge undertaking, encompassing some seventy volumes, the Köseishinpen was ultimately abandoned, incomplete (Keene 1969: 75). 
This government project was preceded by and, to some extent, made possible by the earlier production of the Haruma Wage dictionary already mentioned. Three of the compilers of this dictionary, Inamura Sanpaku (稲村三伯), Udagawa Genshin (宇田川玄真), and Okada Hosetsu (岡田甫説), had been students of Ötsuki prior to his employment by the government (Goodman 2000: 140). The dictionary's importance in challenging the undifferentiated patronage of the shoguns is attested in the increase in Rangaku schools that followed its completion. In 1800, there were only six Rangaku schools in Japan. However, in the following years this number quickly leapt up to thirty-four (Cullen 2003: 133). These schools appeared around Japan, and especially in Nagasaki, further eroding the undifferentiated patronage of the government by calling on the expertise of the collegium of interpreters, and increasingly, the inhabitants of Dejima themselves (Cullen 2003: 133). The schools produced individuals familiar with European science and Dutch language who were able to produce translations for patrons that may even be sold on the open market.

By the early nineteenth century, therefore, there is a perceivable shift in the nature of Japan's isolationism, both in terms of its rationale and its enforcement. While the inhabitants of Dejima were still by no means free, their treatment had lost much of its earlier quarantine-like feel. The historical taboo attached to anything Christian was also being replaced by something of a growing exotic interest in European culture. The Seishukan (成秀館), one of Nagasaki's Rangaku schools, founded by interpreter Yoshio Kōgyū (吉雄耕牛), is a case in point. It held a large collection of Dutch artefacts and became a popular attraction within the city (Katagiri 2004: 636). Another of Nagasaki's Dutch schools, the Naritaki-juku (鳴滝塾) was even founded in 1824 by the then physician to Dejima, the German Philipp Franz Balthasar von Siebold, and boasted a functioning, European clinic (Cullen 2003: 152). Thus, the patronage of translations and intercultural communication that had earlier been unambiguously undifferentiated, being the exclusive province of the ruling shogun, had now become differentiated in every respect. Translation was now not only a governmental concern but was conducted under the patronage of academics and even the general public, both in the form of medical advice and in the form of written translations.

However, it was not long before the government came again to perceive translation as a threat to isolationism, and sought to bring it under control. During the course of his stay in Japan, von Siebold, a botanist as well as a physician, amassed an enormous collection of plant and animal specimens (Goodman 2000: 185-186). While on an official trip to Edo in 1826, he also had the chance to mix with the scholars there, notably Takahashi Kageyasu (高橋景保) of the Banshowagegoyō, who had furnished him with detailed maps of Japan and Korea (Goodman 2000: 185). Though it is highly doubtful von Siebold's intentions were anything other than academic, when in 1828 his possession of the map came to light, the government's reaction was one of outrage (Goodman 2000: 186). Von Siebold was tried for a crime equivalent to high treason on the basis that such maps had the potential of facilitating a foreign invasion (Keene 1969: 149). Having permanently expelled him, the government began re-evaluating the wisdom of differentiated translation patronage.

Around a decade later, in 1839, Rangaku scholarship was linked to criticism of isolationism, which remained national policy, and the "Indictment of the Society for Barbarian Study” (蛮社の獄/Bansha no Goku) was issued (Jansen 1984: 546). Then, in 1849 the overwhelmingly differentiated patronage and its relatively ad hoc 
approach to translation were brought to an end under the Order to Control the Translation of Dutch Writing (蘭書翻訳取締令/Ransho-honyaku-torishimari-rei). Permission would now be required prior to undertaking a translation, or even importing the source texts, which were, once again, subject to strict monitoring (Sugaya 1976: 4).

These measures were, however, relatively short-lived. In 1853, American Naval Commodore Matthew Perry arrived in Uraga harbour near Edo, and through military force, compelled the Japanese government to reopen the country (Craig 1961: 86). What ensued over the following fifteen years or so encompassed what is traditionally referred to as the Meiji restoration, in which the hereditary shoguns' temporal power was reconsolidated in the personage of the Meiji Emperor, whose position had historically been largely symbolic (Harootunian 1970: 297).

In many ways, the belligerent attitude of Perry, together with the continued domination of many of Japan's neighbours such as Vietnam, the Philippines, Indonesia, Hong Kong, and Malaysia at the hands of European imperial powers confirmed the fears that had led the shoguns to adopt and maintain isolationism. However, Perry's display of modern military technology persuaded the authorities that isolationism was no longer an effective means of avoiding colonization if the discrepancy between Japan's military capacity and that of the expansionist powers remained so marked. Seeing the Opium Wars in China as diverting the attention of these expansionist powers for the time being, Japan abandoned isolationism, reversed its restrictions on translation, and rather than avoiding contact with the perceived aggressors, sought instead to understand them through a subsequent massive translation boom (Haag 2011: 20-21).

\section{Conclusion}

The patronage of translation practices in isolationist Japan began unambiguously undifferentiated. The collegium of interpreters was given a monopoly over the profession and, in return, acted as the front lines in maintaining national policy. This state of affairs is then, a neat illustration of Lefevere's conceptualization of undifferentiated patronage. However, in the final years of the same period, patronage within the same system is clearly differentiated.

Lefevere's conceptualization of this relationship logically sees the "double control factor" as made up of the translators and patrons, both of whom act in their own interests, and having a limiting effect, ultimately preventing translation from challenging the status quo, and acting to perpetuate the system. Indeed, in this example, it was clearly in both parties' interests to ensure that isolationism, and the shoguns' reign continued. Nonetheless, the shift in the nature of patronage did not occur wholly as a result of factors external to the system. The actions of both the patrons and the collegium ultimately weakened their own positions. In promoting the translation of Dutch writings by individuals other than the collegium, the shogun ended the collegium's historical monopoly. In turn, this act created a readership outside the government in physicians and Rangaku scholars. These extra-governmental readerships forced translation patronage to become increasingly differentiated, a process whose strength and speed appears only to have increased until the country's borders were reopened. 
To some extent, these findings problematize Lefevere's conceptualization of patronage as it functions in the production of translations. Partly as a result of its academic heritage, this paradigm currently conceptualizes a system as being stable and, to some extent, self-perpetuating. Within such a system, patronage, one of the control factors that function to maintain this stability, can readily be conceived as either differentiated or undifferentiated in a static, dualistic sense. However, cultural or linguistic systems can rarely be assumed to remain static indefinitely, even when artificial measures such as those found in the Japanese case are set in place. Lefevere's paradigm currently has no way of accounting for this case's transition between differentiated and undifferentiated patronage that occurred in a relatively fluid, seamless, and rapid manner. If the snapshot approach to history is relied upon, it is a relatively simple affair to describe a system's patronage at a particular moment as either differentiated or undifferentiated. However, if a greater expanse of time is taken into account, the fluidity and dynamism that exists between these two categories comes into sharper relief.

Moreover, conceiving patrons and translators as constituting a "double control factor" risks conflating the two parties' intentions with their actions, and the ultimate effects of those actions. This case study has demonstrated that the "double control factor" can only describe the perceived intentions of the two parties involved in the patron-professional relationship, and not their actions. It appears likely that in many cases, shifts in the nature of a system's patronage might well arise, as in this example, from what can only be assumed to be the unintended consequences of one or both of these same parties' actions.

However, these potential weaknesses to Lefevere's patronage paradigm, which are arguably inherited from the general systems theory tradition, need not be conceived as deleterious to the paradigm's use in historical translation research. The synchronic nature of Lefevere's paradigm, together with its conception of the system as self-perpetuating, has been argued here to be most apt to describe cultures at definable, static points in their development. Thus, as is also demonstrated in this article, it is possible to define patronage at two or more such specific points in time within the same culture. These discrete points may then be used as a framework for the exploration of the historical factors that brought about any observed discrepancies and, potentially, the moments at which shifts in patronage actually occurred.

\section{ACKNOWLEDGEMENTS}

I would like to thank the members of the Japanese Studies Writing Workshop at the Sainsbury Institute for the Study of Japanese Arts and Cultures for reading and commenting on the early manuscript. I would also like to thank the reviewers and editors for their kind guidance and patience.

\section{NOTES}

1. The Portuguese were given a monopoly by the Chinese authorities in 1547 to act as intermediaries. Thus a hugely lucrative trade route was set up with Macao at its centre. Chinese silk was acquired in Guangzhou, transported to Macao, and shipped to Nagasaki, where it was traded for Japanese silver (Bharne 2013: 173).

2. For a fuller account of the Japanese foreign policy of the time, together with details about the four contact points Japan maintained with other nations during this period (Kazui and Videen, 1982). 
3. Bugyō (奉行) were offices set up by the central government to administer the shogun's multiple personal estates, as opposed to those that were held by feudal lords, or Daimyo (大名). These estates included many sites of political or financial importance such as the former capital cities of Kyoto and Nara, as well as the trading hubs of Osaka and Kanagawa (Toyama 1988: 18). The various bugyō were directly accountable to the shogun, unlike the regional feudal lords, who had a degree of autonomy in their own domains (Laver 2011: 67).

4. All translations in this article have been prepared by the author unless otherwise referenced.

5. The position of head of the inspectorate of books (書物改役) was made another hereditary office in 1685, when Mukai Gensei (向井元成), a book merchant, came across a Christian text that had evaded censorship and was duly appointed to the office.

6. Sakanishi (1937: 297) notes that around one-third of the proscribed Chinese works fall into the category of local histories of China, and only mention Christian monuments, missions, or missionaries in passing.

7. Sakanishi (1937: 295-296) finds sixty-seven of sixty-eight titles that are listed as having been intercepted on import to Japan between 1685 and 1720 .

8. The Japanese developed a method for deciphering Chinese texts that made use of a form of mental translation known as kanbun-kundoku [Chinese text-Japanese reading]. Diacritics were added to the source text to indicate the order in which the ideograms should be read in order to be comprehensible in Japanese. For a detailed study see Wakabayashi (2005).

9. The other seven translators were Maeno Ryōtaku (前野良沢), Nakagawa Junan (中川淳庵), Katsuragawa Hoshū (桂川甫周), Katsuragawa Hosan (桂川甫三), Hiraga Gennai (平賀源内), Odano Naotake (小田野直武), and Yoshio Kozaemon, one of the Nagasaki interpreters who had founded the first Dutch studies school in Edo (Sugita and Ogata 1984).

10. These leading lights were Udagawa Yōan (宇田川榕莒), the son of Udagawa Genshin, one of the compilers of the Haruma dictionary; and Aochi Rinsō (青地林宗), who had studied at the school of the same Udagawa Genshin.

\section{REFERENCES}

Berger, Shlomo 2005. Translation between language and culture: Benjamin of Tudela's Travels in Yiddish (Amsterdam 1691): Inaugral Lecture As Professor of Yiddish Language and Culture at the Universieit Van Amsterdam on November 2 2005, Amsterdam: Vossiuspers UvA.

Bharne, Vinayak 2013. The Emerging Asian City: Concomitant Urbanities and Urbanisms, New York: Routledge.

Chomel, Noël 1718. Dictionnaire oconomique contenant divers moyens d'augmenter son bien, et de conserver sa santé, Lyon: Chez L. Bruyset.

Nederlandsche Oost-Indische Compagnie, Comptoir Nagasackij and Tokyo Daigaku Shiryo Hensanjo 1974. Dagregisters gehouden bij de opperhoofden van het Nederlandsche Faktorij in Japan, Tokyo: Tokyo Daigaku Shiryo Hensanjo.

Craig, Albert M. 1961. Chōshū in the Meiji Restoration, Cambridge: Harvard University Press. Cullen, L. M. 2003. A History of Japan, 1582-1941: Internal and External Worlds, Cambridge, UK, New York: Cambridge University Press.

De Bary, William Theodore, Keene, Donald, Tanabe, George and Varley, Paul 2006. Sources of Japanese tradition. Vol 1. New York: Columbia University Press.

De Chalmot, Jacques Alexandre \& Chomel, Noël 1768. Huishoudelijk woordenboek, vervattende veele middelen om zijn goed te vermeerderen, en zijne gezondheid te behouden,: met verscheidene wisse en beproefde middelen voor een groot getal van ziektens, en schoone geheimen, om tot een hoogen en gelukkigen ouderdom te geraaken, Leiden: H.A. de Chalmot.

De Groot, Henk 2010. Engelbert Kaempfer, Imamura Gen'enmon and Arai Hakuseki. An Early Exchange of Knowledge between Japan and the Netherlands. In: Huigen, Siegfried, De Jong Jan L., and Kolfin, Elmer (eds.) The Dutch Trading Companies as Knowledge Networks. Leiden; Boston: Brill, 201-210. 
Van Der Velde, Paul 1995. The Interpreter Interpreted: Kaempfer's Japanese Collaborator Imamura Genemon Eisei. In: Bodart-Bailey, B. M. \& Massarella, D. (eds.) The Furthest Goal: Engelbert Kaempfer's Encounter with Tokugawa Japan. Sandgate: Japan Library, 44-58.

Goodman, Grant Kohn 2000. Japan and the Dutch, 1600-1853, Richmond, Surrey: Curzon.

VAn GuliK, Thomas M and Nimura, Yuji 2005. Dutch surgery in Japan. World journal of surgery, 29, 10-17.

HAAG, Andre 2011. Maruyama Masao and Katō Shūichi on Translation and Japanese Modernity. In: Levy, I. A. (ed.) Translation in Modern Japan. Milton Park, Abingdon, Oxon; New York: Routledge, 15-43.

Harootunian, Harry D. 1970. Toward Restoration: The Growth of Political Consciousness in Tokugawa Japan, Berkeley: University of California Press.

Hesselink, Reinier H. 1995. A Dutch New Year at the Shirandō Academy. 1 January 1975. Monumenta Nipponica, 50, 189-234.

Jansen, Marius B. 1984. Rangaku and Westernization. Modern Asian Studies, 18, 541-553.

Jansen, Marius B. 2002. The Making of Modern Japan, Cambridge, Massachusetts: Belknap Press of Harvard University Press.

Kaempfer, Engelbert, Haberland, Detlef (ed.) and Michel, Wolfgang (ed.) 2001. Werke: kritische Ausgabe in Einzelbänden, Vol 2. München: Iudicium.

Kaempfer, Engelbert and Scheuchzer, John Gaspar 1727. The history of Japan, giving an account of the ancient and present state and government of that empire: of its temples, palaces, castles and other buildings, of its metals, minerals, trees, plants, animals, birds and fishes, of the chronology and succession of the emperors, ecclesiastical and secular, of the original descent, religions, customs, and manufactures of the natives, and of their trade and commerce with the Dutch and Chinese: together with a description of the kingdom of Siam, London: Printed for the translator.

KATAGIRI, Kazuo 1995. 阿蘭陀通詞今村源右衛門英生: 外つ国の言葉をわがものとして [Dutch interpreter Imamura Gen'emon Eisei: in foreign words]. Tokyo: Maruzen Kabushiki Kaisha.

Katagiri, Kazuo 2000. 出島 [Dejima]. Tokyo, Shueisha.

KATAGIRI, Kazuo 2004. 江戸時代, 東西医学の対話 : 吉雄幸左衛門耕牛を中心として [Bridge between Oriental and Western medicine in Edo era: Focusing on Dr Yoshiwo Kozaymon Kōgyū]. Japanese Journal of Oriental Medicine, 55, 627-638.

Kazui, Tashiro \& Videen, Susan Downing 1982. Foreign Relations during the Edo Period: Sakoku Reexamined. Journal of Japanese Studies, 8, 283-306.

Keene, Donald 1969. The Japanese Discovery of Europe, 1720-1830, Stanford, Calif.: Stanford University Press.

Laver, Michael S. 2011. The Sakoku Edicts and the Politics of Tokugawa Hegemony, Amherst, New York: Cambria Press.

Lefevere, André 1982. Mother Courage's Cucumbers: Text, System and Refraction in a Theory of Literature. Modern Language Studies, 12, 3-20.

Lefevere, André 1984. That structure in the dialect of men interpreted. Comparative Criticism, $6,87-100$.

LEFEVERe, André 1992. Translation, rewriting, and the manipulation of literary fame, London: Routledge.

Lidin, Olof G. 2002. Tanegashima: the arrival of Europe in Japan, Copenhagen: NIAS Press.

MASAKI, Anno 2000. バテレン追放令再考 [Second thoughts on the deportation order of Jesuits]. Crossroads: Hirosaki University Academics' Collection, 2, 1-7.

Mestler, G. E. 1957. Introduction to Western influences in pre-Meiji Japanese medicine. Proceedings of the Royal Society of Medicine, 50, 1005-13.

Mozumi, Jitsuo 1996. 英学の成立 [The establishment of English studies]. In: Ōkura Seishin Bunka Kenkyūsho (ed.) 近世の精神生活 [Spritual Life in the Early Modern Period], Tokyo: Zoku Gunsho Ruijū Kanseikai, 833-869.

Mungello, D. E. 2009. The Great Encounter of China and the West, 1500-1800, Lanham: Rowman \& Littlefield Publishers. 
Ōкuво, Toshiaki 1986. 幕末維新の洋学 [Western studies in the late Tokugawa and early Meiji periods]. Tokyo: Yoshikawa Kobunkan.

ŌTORI, Ranzaburo 1964. Acceptance of Western medicine in Japan. Monumenta Nipponica, 19, 254-274.

OzawA, Tatsuo 1982. 日本科学史入門 [Introduction to the history of Japanese science]. Tokyo: Hirokawa Shoten.

Pacheco, Diego 1970. The Founding of the Port of Nagasaki and its Cession to the Society of Jesus. Monumenta Nipponica, 25, 303-323.

Phan, Peter C. 2011. Christianities in Asia, Malden, Massachusetts: Wiley-Blackwell.

RoBerts, Lissa 2009. Frontier Tales: Tokugawa Japan in Translation. In: SchAfFer, S. (ed.) The Brokered World: Go-betweens and Global Intelligence, 1770-1820. Sagamore Beach, Mass.: Science History Publications, 1-47.

Rudolph, Richard C. 1974. Thunberg in Japan and his Flora Japonica in Japanese. Monumenta Nipponica, 29, 163-179.

Sakanishi, Shio 1937. Prohibition of Import of Certain Chinese Books and the Policy of the Edo Government. Journal of the American Oriental Society, 57, 290-303.

SAkula, Alex 1985. Kaitai Shinsho: The Historic Japanese Translation of a Dutch Anatomical Text. Journal of the Royal Society of Medicine, 78, 582-587.

SHIDō, Sadaaki and YABE, Ichirō 1991. 近代日本その科学と技術 : 原典への招待 [The science and art of early-modern Japan: an introduction to its texts]. Kawasaki-shi: Kogaku Shuppan.

Sмiтн, Thomas Carlyle 1948. The Introduction of Western industry to Japan during the last years of the Tokugawa period, Harvard Journal of Asian Studies. 11: 130-152

SugAYA, Akira 1976. 日本医療制度史 [A history of the Japanese health care system]. Tokyo: Hara Shobo.

Sugita, Genpaku and Tomio, Ogata 1984. 現代文蘭學事始 [The beginnings of Dutch studies in modern Japanese]. Tokyo: Iwanami Shoten.

TANABE, Hiroshi 1989. 江戶時代におけるくすり・医・くらし : 徳川理財会要の抜粋 $[$ Medicines, medical care and living standards during the Edo period: excerpts from the cornerstones of the Tokugawa treasury]. Gifu: Naito Kinen Kusuri Hakubutsukan.

Thunberg, Carl Peter 1788. Resa uti Europa, Africa, Asia: förrättad åren 1770-1779. Vol. 3 Uppsala: Joh. Edman.

Tomaya, Mikio 1988. 長崎奉行: 江戶幕府の耳と目 [Nagasaki bugyō: the eyes and ears of the Edo bakufu]. Tokyo: Chuo Koronsha.

WakabaYASHI, Judy 2005. The Reconceptualization of Translation from Chinese in 18th-century Japan. In: Hung, E. (ed.) Translation and Cultural Change: Studies in History, Norms, and Image Projection. Amsterdam, Philadelphia: John Benjamins, 119-146.

Yокоунма, Hiroaki 2011. 長崎唐人屋敷の謎 [The mystery of the Nagasaki residence for Chinese people]. Tokyo: Shueisha. 